\title{
AMBIGUITAS PERLAWANAN PAJAK LEMBAGA PERKREDITAN DESA (STUDI FENOMENOLOGI PADA LEMBAGA PERKREDITAN DESA DI PROVINSI BALI)
}

\author{
I Gede Yudi Primanta \\ Made Sudarma \\ Aji Dedi Mulawarman \\ Universitas Brawijaya \\ yudiprimanta@gmail.com
}

\begin{abstract}
The research aims to understand businessmen' tax awareness and tax resistance for their business in Lembaga Perkreditan Desa (LPD). The research applies qualitative methode with transcendental phenomenology. The results of the study shows that LPD is supposed to be discharged from the tax duty. LPD has a significant role in preserving the custom and culture of Bali. Besides, some LPD businessmen are aware of their tax duty charged for running the LPD.
\end{abstract}

Keywords:

LPD; transcendental phenomenology; tax resistance; custom; culture

Pajak merupakan sumber penerimaan terbesar negara. Lebih dari tujuh puluh persen Anggaran Pendapatan dan Belanja Negara (APBN) ditopang dari penerimaan pajak. Hanya saja, target penerimaan pajak yang besar untuk membiayai APBN tersebut seringkali tidak tercapai. Pada tahun 2015 dari target penerimaan pajak sebesar Rp1.294 triliun yang merupakan 73,48 persen dari total penerimaan negara sebesar Rp1.761 triliun hanya tercapai sebesar Rp1.055 triliun atau hanya $81,53 \%$ dari target (Kementerian Keuangan, 2016b).

Meningkatnya penerimaan pajak dalam rangka membiayai pembangunan tidak bisa hanya mengandalkan peran fiskus dalam melakukan pemungutan, melainkan kesadaran dan kepatuhan masyarakat dalam membayar pajak sesuai dengan ketentuan perpajakan yang berlaku merupakan faktor yang paling penting. Tuntutan akan kesadaran dan kepatuhan membayar pajak dimulai dari wajib pajak sendiri tercermin dalam Undang-Undang (UU) Perpajakan di Indonesia yang menganut self assesment system. Adapun peran fiskus sebatas mengawasi kewajiban perpajakan dari wajib pajak (WP) apakah telah sesuai dengan ketentuan perundang-undangan. Sayangnya kesadaran yang kemudian diejawantahkan sebagai kepatuhan dalam menjalankan kewajiban perpajakan sesuai dengan peraturan perundang-undangan yang berlaku, terbilang masih rendah. Hal ini diindikasikan dengan tax ratio Indonesia yang masih dibawah standar jika dibandingkan dengan beberapa negara di kawasan ASEAN yang tergolong bagus perekonomiannya. Tax ratio Indonesia saat ini masih di kisaran 11 persen, tertinggal jauh dari Singapura, Malaysia, dan Thailand.

Telah banyak penelitian di Indonesia bahkan internasional yang dilakukan untuk menemukan apa yang mendasari sehingga individu memiliki kesadaran dan kepatuhan dalam menjalankan kewajiban perpajakan, atau malah sebaliknya. Hasil penelitian Kariyoto dkk. (2010) yang bermaksud menguji pengaruh kesadaran dan kepatuhan terhadap kinerja perpajakan mendapatkan hasil bahwa kesadaran dari WP berpengaruh terhadap perpajakan dan kepatuhan wajib pajak itu sendiri, walaupun kesadaran tersebut tidak berpengaruh terhadap kinerja perpajakan. Selain itu didapatkan pula temuan lain bahwa kinerja perpajakan dipengaruhi oleh kepatuhan wajib 
pajak. Torgler (2004) menjadikan tax morale sebagai variabel dependen dalam menganalisis apa yang membentuk tax morale pada negara-negara di Asia. Tax morale didefinisikan sebagai motivasi intrinsik untuk membayar pajak yang kemudian diukur dengan pembenaran untuk melakukan kecurangan pajak. Temuan penelitiannya, kepercayaan kepada pemerintah dan sistem hukum berdampak positif terhadap tax morale, faktor budaya juga memengaruhi tax morale.

Alm dan Torgler (2006) dengan menggunakan data World Values Survey (WVS) meneliti pengaruh budaya terhadap tax morale. Penelitian dilakukan dengan menggunakan analisis crosssection terhadap individu di Spanyol dan Amerika Serikat (AS). Temuannya, (1) individu di AS memiliki tax morale tertinggi dibandingkan dengan negara lainnya yang ikut dianalisis; (2) terdapat korelasi negatif yang kuat antara ukuran ekonomi informal dengan tingkat tax morale pada negaranegara tersebut. Selanjutnya Torgler (2006) meneliti pengaruh religiousitas terhadap tax morale dengan menggunakan data dari WVS tahun 1995-1997 yang meliputi tiga puluh negara. Variabel independen yang digunakan dalam penelitian meliputi kehadiran ke tempat ibadah, partisipasi dalam kegiatan keagamaan, religius, pentingnya agama, petunjuk agama, kepercayaan pada lembaga agama, pendidikan, kepuasan ekonomi, menghindari risiko, kelas ekonomi, kebohongan, kecurangan, dan membeli produk curian. Hasilnya menunjukkan bahwa religiousitas berpengaruh terhadap tax morale. Tingkat religiositas seseorang yang tinggi akan meningkatkan tax morale.

Selain menggunakan pendekatan kuantitatif, beberapa penelitian mengenai kepatuhan dan kesadaran akan kewajiban perpajakan juga menggunakan pendekatan kualitatif, seperti Fidiana (2014), yang melakukan penelitian dengan paradigma tauhid untuk mengungkap kesadaran/kepatuhan terhadap pajak pada suatu komunitas muslim keturunan Arab. Hasil penelitiannya menunjukkan bahwa terdapat perbedaan perilaku antara kepatuhan memenuhi kewajiban agama dalam bentuk zakat dengan kepatuhan atas kewajiban perpajakan. Fidiana (2014) pula mengungkapkan ketidakpatuhan terhadap kewajiban perpajakan juga disebabkan oleh perilaku fiskus, birokrat, dan instansi pemerintahan, serta kesulitan dalam memahami administrasi perpajakan.

Dari sisi kearifan lokal, Darmayasa dan Aneswari (2016) mencoba untuk menggali bagaimana kearifan lokal berperan terhadap kepatuhan pajak yang dalam hal ini diwakili oleh LPD, yaitu lembaga keuangan yang ada di provinsi Bali. Temuan penelitian menunjukkan bahwa selama ini LPD melakukan kegiatan usaha layaknya lembaga keuangan tetapi belum memiliki Nomor Pokok Wajib Pajak (NPWP), padahal NPWP merupakan langkah awal dalam pelaksanaan pemenuhan kewajiban perpajakan. Tidak dimilikinya NPWP menyebabkan LPD tidak membayar pajak penghasilan yang seharusnya menjadi kewajiban bagi setiap orang atau badan usaha yang menghasilkan profit. Hal tersebut juga tidak lepas dari cara pandang bahwa laba operasional yang diperoleh LPD sebesar dua puluh persen telah dikontribusikan bagi kepentingan pembangunan tempat ibadah. Kontribusi pada tempat ibadah adalah sebagai bentuk Corporate Social Responsibility (CSR). Cara pandang ini berbeda dengan cara pandang fiskus, bahwa seharusnya LPD memiliki NPWP dan membayar pajak penghasilan badan, dan memungut dua puluh persen pajak atas penghasilan bunga yang diterima oleh nasabah LPD. Darmayasa dan Aneswari (2016) juga menemukan bahwa ketidakpatuhan yang ditunjukkan dengan tidak memiliki NPWP bukan sesuatu yang diniatkan sebagaimana tindakan yang direncanakan dalam penelitian Ajzen (1991). Tindakan ini menurut Darmayasa dan Aneswari (2016) merupakan bentuk tax avoidance. Terakhir, sama dengan hasil penelitian sebelumnya, LPD dalam menjalankan kegiatan usaha LPD berlandaskan pada filosofi Tri Hita Karana (THK) (Bagiada dan Darmayasa, 2015; Damayanthi, 2011; Djayastra, 2012; Gunawan, 2011; Pertiwi dan Ludigdo, 2013). Filosofi THK lahir dari suatu kearifan lokal masyarakat Hindu Bali.

Mengingat peranan LPD yang cukup besar dalam membantu pemberdayaan ekonomi masyarakat adat di Bali (Djayastra, 2012) serta asetnya yang mencapai Rp14,2 triliun (Bisnis.Com, 2015) di seluruh Bali, mengalahkan total aset dari lembaga keuangan sejenis seperti BPR yang hanya sebesar Rp10,34 triliun (Bank Indonesia Perwakilan Bali, 2015) ternyata tidak dibarengi dengan pemenuhan kewajiban perpajakan. Dari isi pasal UU Nomor 36 Tahun 2008 yang 
menyebutkan secara jelas siapa saja yang dikecualikan dari subjek pajak menunjukkan bahwa LPD tidak mendapatkan pengecualian dari kewajiban perpajakan.

Pentingnya pajak bagi suatu negara sebenarnya juga sudah dikenal lama dalam kehidupan masyarakat Bali. Pada masa itu mekanisme pemungutan pajak dilakukan oleh petugas pemungut pajak yang kemudian pembayaran pajak dari masyarakat diserahkan oleh pemungut pajak kepada raja. Pajak yang dibayarkan masyarakat kepada kerajaan pada masa itu cukup banyak, diantaranya: pajak atas tanah, pajak kesenian, pajak peternakan dan pajak atas usaha tertentu (Budiasih, 2014).

Jenis pajak yang relatif banyak ternyata tidak terlalu berpengaruh terhadap rakyat dalam memenuhi kewajiban membayar pajak, rakyatnya ikhlas membayar pajak. Keikhlasan masyarakat ini timbul karena kepercayaan yang tinggi kepada raja serta adanya kepercayaan akan administrasi dan akuntabilitas perpajakan kerajaan yang dibuat oleh raja. Rakyat percaya bahwa pajak yang dibayar ditujukan untuk pembangunan dan perkembangan kesejahteraan masyarakat. Masyarakat juga percaya bahwa raja dalam membangun kesejahteraan dapat bersikap adil dan bertanggungjawab (Budiasih, 2014; Kamayanti, 2015).

Mengapa saat ini LPD yang melakukan kegiatan usaha dan menghasilkan laba belum menjalankan kewajiban perpajakan yang berlaku di Indonesia? Dalam peradaban Hindu dan kehidupan di Bali sejak zaman Bali kuno, kewajiban perpajakan itu sudah ada dan diberlakukan. Apakah terdapat cara pandang berbeda terhadap konsep perpajakan yang saat ini berlaku di Indonesia, yang menyebabkan para pelaku kegiatan usaha LPD merasa bahwa mereka tidak perlu memenuhi kewajiban perpajakan yang berlaku di Indonesia yang diatur dengan peraturan perundang-undangan? Hal ini sedikit kontradiktif, karena dalam menjalankan kegiatan usahanya, LPD menjadikan ajaran Hindu sebagai dasar filosofis yang mana dalam ajaran Hindu menghormati dan mematuhi pemerintah adalah salah satu bentuk tanggung jawab umat Hindu dalam menjalankan kehidupan.

Berdasarkan fenomena bahwasanya sampai dengan saat ini LPD tidak menjadi subjek pajak dan tidak menjalankan kewajiban perpajakan sebagaimana lembaga keuangan lainnya, menjadi hal yang menarik untuk diteliti. Mengapa hal ini bisa terjadi? Apa yang menyebabkan LPD sebagai suatu lembaga yang melakukan kegiatan usaha dengan mendasarkan pada ajaran Hindu dan budaya Bali tidak menjadi subjek pajak padahal dalam ajaran Hindu dan kehidupan masyarakat Bali dari masa lampau, konsep perpajakan sudah dikenal dan bahkan jenis pajak yang dibayarkan sangat beragam jenisnya tetapi rakyat pada masa itu ikhlas untuk membayar pajak? Apakah permasalahan ini timbul karena adanya cara pandang berbeda dalam memandang tanggung jawab pajak pada masa sekarang yang dinilai tidak sejalan dengan pandangan masyarakat Bali, khususnya terkait kegiatan usaha LPD? Hal-hal tersebut menjadikan pertanyaan yang ingin dijawab dalam penelitian ini, yaitu bagaimana kesadaran pelaku usaha LPD terhadap pajak sehingga LPD tidak menjalankan kewajiban perpajakan yang berlaku di Indonesia.

Secara umum, kajian ini bertujuan mengungkap kesadaran pelaku usaha LPD terhadap pajak yang menjadi penyebab LPD belum menjalankan kewajiban perpajakan yang berlaku. Pada akhirnya dari hasil kajian ini, diharapkan dapat menambah khasanah pengetahuan terkait suatu lembaga ekonomi yang bergerak dengan filosofi spiritual Hindu dikaitkan dengan pelaksanaan kewajiban perpajakan serta sebagai bahan masukan dalam mengatasi perbedaan pendapat terkait status perpajakan LPD dari sudut pandang LPD dan dari sudut pandang fiskus.

\section{METODE}

Penelitian ini berjenis kualitatif dengan pendekatan fenomenologi transendental. Pendekatan fenomenologi transendental digunakan untuk mengungkap kesadaran terhadap pajak dan penolakan untuk menjalankan kewajiban perpajakan dari sudut pandang para pelaku usaha LPD. Menurut Thevenaz dalam Burrel dan Morgan (1979), fenomenologi transendental memiliki filosofi yang mencoba untuk memahami bahwa dunia ini sebagai fenomena bukan merupakan objek, tetapi memiliki makna yang murni (pure meaning). Pendekatan fenomenologi transendental adalah suatu pemikiran yang identik sebagai karya Edmud Husserl. 
Terdapat beberapa kata kunci yang terkandung dalam analisis fenomenologi transendental yang kemudian digunakan oleh peneliti sebagai landasan dalam melakukan penelitian, yaitu: Noema, Noesis, Epoche (Bracketing), Intentional Analysis, dan Eidetic Reduction. Selain itu, juga digunakan intuisi dan intersubjektivitas yang merupakan unsur penting dalam penelitian fenomenologi (Kuswarno, 2009).

Penelitian ini dilakukan pada empat LPD yang berada di empat desa Pakraman, dua LPD berapa di kabupaten Badung dan dua lainnya berada di kabupaten Tabanan. Fokus dari subjek penelitian ini adalah pengurus LPD yang bertanggung jawab dalam memimpin operasional serta fiskus dan individu yang terlibat dalam lembaga pengawas LPD. Objek penelitian ini adalah kesadaran terhadap pajak dan penolakan menjalankan kewajiban perpajakan yang sebenarnya merupakan suatu bentuk kewajiban kepada negara.

Kriteria yang digunakan dalam mengkatagorikan LPD tersebut sebagai LPD kecil, menengah, dan besar adalah berdasarkan aset yang dimilikinya. LPD yang dikategorikan kecil adalah LPD yang asetnya tidak lebih dari Rp10 milyar, LPD menengah adalah LPD yang asetnya lebih dari Rp10 milyar tetapi tidak melebihi Rp 50 milyar, dan LPD yang dikategorikan besar adalah LPD yang asetnya melebihi Rp 100 milyar.

Fenomenologi transendental sebagaimana diungkapkan oleh Kamayanti (2016), tidak mungkin mengambil lebih dari sepuluh informan karena mengupas "Aku" yang dilakukan oleh peneliti dalam penelitian fenomenologi sangat melelahkan apabila peneliti benar-benar melakukan fenomenologi. Peneliti mendapatkan tujuh informan yang bersedia untuk diwawancarai. Empat informan merupakan pengurus LPD, satu informan adalah Kepala Lembaga Pengawas LPD (LPLPD), dan dua informan adalah pegawai pajak.

Sumber data dalam penelitian kualitatif termasuk di dalamnya penelitian dengan pendekatan fenomenologi berasal dari kata-kata dan tindakan, serta data tambahan berupa seperti dokumen dan lain-lain (Lofland dan Lofland dalam Moleong, 2014). Penelitian ini mengutamakan data yang bersumber dari kata-kata dan tindakan informan sebagai data primer, sedangkan data tambahan yaitu data sekunder berupa laporan keuangan, data-data mengenai kegiatan usaha, serta peraturan-peraturan yang berkaitan dengan pajak dan LPD.

Pengumpulan data pada penelitian ini menggunakan metode wawancara tidak terstruktur. Pemilihan wawancara tidak terstruktur dikarenakan penelitian ini ditujukan untuk mengungkap makna dari subjek, sehingga kedalaman pertanyaan diperlukan. Penggunaan wawancara tidak terstruktur juga dapat mengeksplorasi sudut pandang informan mengenai permasalahan yang dibahas dalam penelitian ini. Pengamatan yang dilakukan peneliti yaitu dengan mengamati ekspresi, situasi, dan kondisi dari informan pada saat melakukan wawancara. Setelah data diperoleh dilakukan pengujian terkait keabsahannya dengan menggunakan metode triangulasi. Metode triangulasi pada penelitian ini adalah memadukan informasi dari informan kunci yaitu pengurus LPD, fiskus, dan pengawas LPD dengan data-data yang berupa kata-kata informan serta data dalam bentuk laporan atau sumber tertulis lainnya.

\section{HASIL DAN PEMBAHASAN}

Hasil

Penelitian ini bertujuan mengungkap kesadaran pelaku usaha LPD terhadap pajak dan kesadaran untuk tidak menjalankan kewajiban pajak sebagaimana mestinya atas kegiatan usaha LPD. Penelitian ini menemukan beberapa hal penting.

Pertama, terkait kesadaran terhadap pajak dan penolakan untuk menjalankan kewajiban perpajakan. Informan memaknai bahwa LPD dibebaskan dari kewajiban perpajakan, pajak sebagai beban yang mengurangi kontribusi LPD, kesadaran bahwa laba LPD telah berperan besar untuk melestarikan adat dan budaya Bali serta semua labanya memiliki tujuan sosial sehingga tidak seharusnya dikenakan pajak, dan adanya pelaku usaha LPD yang menyadari bahwa ada kewajiban perpajakan yang perlu dijalankan oleh LPD. 
Kedua, Peran LPD yang besar dalam melestarikan adat dan budaya Bali tidak lepas dari kepemilikan. LPD dimiliki oleh desa adat yang memang ada dan bertujuan untuk mengatur kehidupan adat dan budaya di Bali dengan menjalankan filosofi Tri Hita Karana. Ketiga, ketidaksediaan LPD untuk dikenakan pajak tidak lepas dari faktor eksternal. Faktor eksternal tersebut adalah ketidakadilan distribusi pendapatan dari pariwisata.

Ketiga, tindakan yang dilakukan LPD untuk tidak memenuhi kewajiban pajak merupakan bentuk perlawanan pajak yang dikategorikan sebagai tindakan melalaikan pajak. Di luar itu, beberapa temuan penelitian ini sejalan dengan Darmayasa dan Aneswari (2016), bahwa UU LKM mengecualikan LPD dari kewajiban pajak, dan pelaksanaan tanggung jawab sosial yang dilakukan oleh LPD ini dipengaruhi oleh filosofi Tri Hita Karana.

Keempat, adanya risiko perlawanan apabila memaksakan untuk menjadikan LPD sebagai subjek dan objek pajak, walaupun sebenarnya LPD memenuhi kriteria subjek dan objek berdasarkan peraturan perpajakan yang berlaku. Risiko ini karena LPD itu dirasakan manfaatnya oleh masyarakat adat di Bali, apabila memaksakan penetapan LPD sebagai subjek pajak maka penolakan ini akan melibatkan seluruh masyarakat adat di Bali.

\section{Pembahasan \\ LPD Harus Dibebaskan Dari Kewajiban Perpajakan}

Legitimasi terhadap LPD melalui UU LKM pula yang menjadi argumen para pelaku usaha LPD bahwasanya LPD tidak kena pajak. LPD tidak perlu mengikuti hukum negara karena telah dikecualikan karena menjalankan kegiatan usaha berdasarkan hukum adat. Pajak hanya dikenakan kepada lembaga keuangan yang berbadan hukum resmi, sedangkan LPD tidak. LPD hanya memiliki kewajiban kepada krama adat di desa adat tempat LPD bernaung.

UU LKM sebagai legitimasi LPD tidak kena pajak telah menjadi kesadaran eksplisit dari setiap pelaku usaha LPD yang peneliti wawancarai. Para informan memiliki kesadaran bersama yang terbentuk bahwasanya dengan berlakunya UU LKM maka LPD memperoleh perlakuan khusus. Salah satu perlakuan khusus itu adalah LPD tidak kena pajak. Hal ini didukung oleh informasi yang didapatkan dari para informan yang konsisten menjelaskan bahwa UU LKM menjadi pembenar bahwa LPD tidak kena pajak. Di luar informan pada penelitian ini, Darmayasa dan Aneswari (2016), yang meneliti peran kearifan lokal terhadap kepatuhan pajak ketika mewawancarai salah satu pengurus LPD mendapatkan jawaban yang kurang lebih sama, bahwa LPD bukan merupakan lembaga keuangan sebagaimana yang diatur dalam Undang-undang sehingga tidak kena pajak.

LPD di Provinsi Bali memiliki karakteristik yang berbeda dengan LPD di provinsi lain. Jika dikaitkan dengan UU Nomor 7 Tahun 1992 Tentang Perbankan yang diubah terakhir dengan UU Nomor 10 Tahun 1998, maka LPD sebagaimana yang dimaksud dalam Pasal 58 adalah LPD yang dimiliki desa dinas. Di daerah lain LPD diisi oleh unsur pemerintah desa yang menjadi pengurus dan berfungsi menggerakkan LPD tersebut, sedangkan di Bali peran pemerintah desa bisa dikatakan minim (Nurjaya, 2011). Nurjaya (2011) juga menyatakan bahwa perbedaan karakteristik LPD di Bali dapat dilihat dari landasan filosofis, visi misi, dan landasan hukumnya. Secara filosofis LPD di Bali berbasiskan hukum adat berupa awig-awig ${ }^{1}$. LPD didirikan serta dikelola dengan awig-awig serta untuk kesejahteraan krama desa. LPD tidak hanya berorientasi profit sebagaimana badan usaha sejenis, melainkan ada nilai religius dan budaya, serta berkaitan dengan kewajiban skala dan niskala. LPD juga memiliki misi untuk menjaga kehidupan budaya Bali dengan menjalankan ajaran THK. Landasan hukum yang diacu oleh LPD adalah Pasal 18B ayat (2) yang mengakui dan menghormati kesatuan masyarakat hukum adat serta hak-hak tradisional asalkan masih eksis dan sesuai dengan perkembangan masyarakat serta Negara Kesatuan Republik Indonesia. LPD yang ada di Bali berbeda dengan konsep yang dianut oleh peraturan-peraturan tersebut. LPD di Bali bukan

\footnotetext{
${ }^{1}$ Awig-awig adalah peraturan yang dibuat oleh desa pakraman yang disahkan dalam paruman (musyawarah) desa pakraman dan wajib untuk dipatuhi dan dilaksanakan oleh krama desa.
} 
merupakan badan usaha publik, melainkan hanya melingkupi masyarakat adat dengan berlandaskan pada hukum adat, serta berorientasi non profit sehingga tidak menjadi objek pajak.

Walaupun ada inisiasi Pemprov Bali dalam pendirian LPD dengan mengeluarkan Pergub dan Perda yang menjadi dasar berkembangnya LPD di Bali, namun peran peraturan tersebut hanya untuk menjaga eksistensi LPD dan menjadikan Pemerintah sebagai pembina dan pengawas LPD hanya sebagai bentuk tanggung jawabnya melindungi dan mengatur kehidupan masyarakat. Pengelolaan dan pengaturan LPD yang lebih spesifik berada dalam lingkup desa Pakraman dengan mengedepankan hukum adat sebagai acuan. Penggunaan hukum adat ini menjadikan LPD di Bali bukan merupakan badan hukum yang menjadi subjek hukum sebagaimana yang dimaksud dalam peraturan perundang-undangan di Indonesia.

Dari penjelasan di atas tidak terlihat secara eksplisit bahwa LPD merupakan badan usaha baik yang berbadan hukum maupun tidak berbadan hukum sebagaimana yang dimaksud dalam hukum negara (Sukandia, 2011). UU Nomor 3 Tahun 1982 tentang Wajib Daftar Perusahaan hanya mengakui badan hukum seperti koperasi, persekutuan perdata, perorangan, dan bentuk-bentuk perusahaan baru sesuai dengan perkembangan perekonomian sebagai badan usaha. LPD hanya didirikan berdasarkan Surat Keputusan Gubernur Bali dan pengaturannya lebih dalam melalui awigawig desa Pakraman. LPD tidak mengenal akta notaris terkait legalisasi pendiriannya. Kegiatannya diatur dengan hukum adat walaupun dalam pengelolaan menggunakan manajemen modern dengan mengadopsi sistem di industri perbankan.

Karena hal di atas, para pelaku usaha LPD memaknai dan memiliki kesadaran bahwa LPD tidak kena pajak. Penolakan itu disebabkan karena dengan menjadi badan usaha yang berbadan hukum ada konsekuensi yang harus ditanggung oleh LPD. LPD kehilangan filosofi dasarnya yaitu lembaga keuangan yang dimiliki oleh krama desa yang memiliki sifat komunal, serta memiliki kewajiban perpajakan karena dengan menjadi badan usaha yang berbadan hukum menjadi kena pajak (Kurniasari, 2007; Nurjaya, 2011). Kesadaran ini yang kemudian peneliti tangkap bahwasanya para informan memiliki pemahaman yang memiliki kewajiban perpajakan adalah badan usaha yang memang memenuhi kriteria badan usaha berdasarkan hukum di Indonesia. Pada titik ini para informan memiliki kesadaran bahwa LPD itu berbeda dengan kriteria badan usaha yang diatur dalam hukum di Indonesia.

Pada tanggal 11 Desember 2012 dalam rapat paripurna yang digelar oleh DPR RI akhirnya RUU Tentang LKM disetujui menjadi Undang-undang. Kemudian pada tanggal 8 Januari 2013 UU ditandatangani oleh presiden sehingga sah menjadi UU Nomor 1 Tahun 2013 Tentang Lembaga Keuangan Mikro. UU ini merupakan kado terindah bagi provinsi Bali yang dari awal telah memperjuangkan agar LPD mendapatkan perlakuan khusus. Bukan saja bagi pemerintah propinsi, berbagai komponen masyarakat Bali, terutama yang terkait dengan LPD berbahagia atas lahirnya undang-undang (UU) ini.

Salah satu pasal dari 42 pasal dalam UU LKM mengakui keberadaan LPD. Pasal 39 ayat 3 pada intinya menyatakan bahwa LPD sebagai lembaga keuangan yang telah eksis sebelum berlakunya Undang-undang LKM diakui keberadaannya sebagai lembaga keuangan yang berdasarkan hukum adat dan tidak tunduk pada UU LKM. Adanya undang-undang ini maka LPD yang sebelumnya selalu diminta oleh pemerintah pusat untuk bertransformasi menjadi badan usaha yang berbadan hukum mendapatkan status khusus dari pemerintah. Kekhususan ini yang kemudian dimaknai oleh informan bahwa LPD dibebaskan dari kewajiban perpajakan sebagaimana yang disampaikan oleh Pak Nyoman salah satu informan berikut ini.

"Sebenarnya terkait pajak, ini sudah jelas, LPD tidak ada kaitan dengan pajak [dengan nada agak pelan dan terkesan menghindari pembahasan terkait judul tesis dan awalnya tidak berkenan wawancara ini direkam sebelum akhirnya berkenan untuk direkam]. UU LKM Pasal 39 sudah mengecualikan LPD. LPD dan Lumbung Pitih Nagari diakui keberadaannya berdasarkan hukum adat dan tidak tunduk pada undang-undang LKM.” [Pak Nyoman, Kepala LP LPD Bali]. 
Kesadaran bahwa laba yang diperoleh LPD tidak dikenakan pajak dan juga tidak perlu memiliki NPWP dikarenakan pemahaman pelaku usaha LPD bahwa LPD itu beroperasi berdasarkan hukum adat sehingga berbeda dengan lembaga keuangan lainnya sebagaimana yang diatur dalam UU LKM seperti yang disampaikan oleh Bapak Baik selaku Kepala LPD TB yang merupakan LPD dengan kategori kecil berikut ini.

"Kalau masalah perpajakan dengan LPD, barangkali kemarin usulan dari provinsi, kita,

LPD itu kan milik desa adat, jadi kita [LPD] itu dikhususkan, karena itu lembaga adat, dimohon untuk tidak kena pajak."

\section{Pajak Merupakan Beban Yang Mengurangi Kontribusi LPD}

Pajak bagi para pelaku usaha LPD dimaknai sebagai beban yang mereduksi kontribusi LPD bagi kesejahteraan krama dan untuk mempertahankan adat dan budaya Bali (lihat tabel 1-Ilustrasi pajak mereduksi kontribusi LPD). Penilaian ini muncul karena tidak ada dampak langsung yang dirasakan oleh para informan apabila LPD membayar pajak terhadap kegiatan adat dan budaya sebagaimana yang disampaikan Bapak GA Kepala LPD P yang merupakan LPD dengan kategori besar.

"Penghasilannya kan untuk kembali pada masyarakat. Desa adat ini kan, adat itu kan agama Hindu Bali. ada pura, ada upakaranya, pura ini kan fisik, upakara kan ritualnya sebagai budaya bali yang sumbernya pariwisata. [selanjutnya yang bersangkutan bercerita tentang berbagai hal terkait investasi LPD untuk membiayai kegiatan desa pakraman sebelum akhirnya menyinggung kata kunci penting berikut ini] Dari LPD dalam bentuk investasi oleh desa adat dengan perhitungan-perhitungannya ini. Baru dia bisa menopang krama itu, kalau [dipajakin] lagi apa pajak bisa memberikan timbal balik?"

Hal sebagaimana yang peneliti ilustrasikan dalam Tabel 1 tidak dapat diterima oleh pelaku usaha LPD. Laba yang seharusnya bisa digunakan secara penuh untuk kesejahteraan krama dalam rangka mempertahankan adat dan budaya berkurang karena menjalankan kewajiban pajak, padahal nominal yang dibayarkan bagi mereka bisa digunakan secara maksimal bagi kepentingan adat dan budaya. Besaran pajak dari laba yang dibayarkan tentu saja akan mengurangi besaran dana yang diberikan LPD kepada desa adat, serta dana yang digunakan untuk aktivitas sosial. Belum lagi apabila diperhitungkan dampak koreksi fiskal yang tentu saja menambah besar pajak yang harus dibayar LPD. Hal inilah yang menjadi anggapan informan bahwa pajak merupakan beban, kemudian sebagai esensi penolakan untuk LPD tidak bersedia dikenakan pajak.

\section{LPD Telah Berperan Besar Melestarikan Adat Dan Budaya Bali}

Pariwisata telah menjadi penggerak dan inti perekonomian dari perekonomian Bali. Pariwisata di Bali dapat berkembang karena keindahan pulau Bali itu sendiri. Tercipta dan terjaganya keindahan pulau Bali lagi-lagi tidak bisa dilepaskan dari nilai-nilai adat yang berakar kuat dari ajaran Hindu yang masih tetap dipegang oleh sebagian masyarakat Bali. Ajaran Hindu melalui Konsep Tri Hita Karana berperan besar dalam menjaga keadaan lingkungan di Bali. Tri Hita Karana merupakan Filosofi Hindu yang menekankan terciptanya keseimbangan hubungan antara manusia dengan Tuhan Yang Maha Esa (parhyangan), manusia dengan lingkungan (palemahan), dan manusia dengan sesama (pawongan) (Bagiada dan Darmayasa, 2015; Damayanthi, 2011; Djayastra, 2012).

Pada titik inilah peran LPD menjadi penting. LPD berperan membantu meringankan beban krama untuk dapat menjaga adat dan budaya Bali. Laba LPD yang diserahkan ke desa Pakraman digunakan untuk membiayai berbagai aktivitas adat dan budaya yang juga merupakan aktivitas keagamaan. Menanggung beban untuk berkontribusi dalam menjaga adat dan budaya membentuk kesengajaan (intentionality) untuk tidak mau dikenakan pajak karena pajak yang dibayar tidak menjamin masyarakat adat dapat mempertahankan adat dan budaya Bali yang menjadi nilai-nilai kehidupan bagi mereka. 
Para informan penelitian mengungkapkan kesadaran mereka bagaimana LPD telah berperan aktif membangun desa Pakraman untuk dapat mempertahankan adat dan budaya Bali. Kesadaran yang dibentuk oleh para informan karena pengalaman dan interaksi dalam mengelola LPD menjadikan adanya pemahaman bahwa LPD bukan saja berfungsi mencari laba, melainkan ada misi sosial budaya yang terkandung dalam aktivitas usaha LPD, yang mana hal tersebut akan tereduksi apabila LPD juga dikenai pajak karena pajak menjadi beban tambahan yang akan ditanggung oleh LPD sebagaimana yang disampaikan oleh salah satu informan yaitu Bapak Ketut yang merupakan Kepala LPD K yang merupakan LPD dengan kategori besar.

"Kalau kita lihat itu, begitu besar biaya yang dikeluarkan oleh rakyat Bali, sehingga Bali pariwisata budaya. Ketika dia berpikir jadi pariwisata budaya berarti kan harus ada sesuatu yang dijual oleh pemerintah. Apa yang dijual ini, orang bali berapa persen menikmatinya dari hasil yang dijual untuk membiayai budaya dan adat? Siapa yang bayar kita kalau adik gotong royong? Pernah pemerintah bayar itu? Siapa yang bayar ketika kita membuat pura besar-besar? Kan ndak ada yang membiayai."

Atas dasar itu, kemudian muncul kesadaran bahwa dengan adanya peran LPD yang melestarikan adat dan budaya sehingga pariwisata Bali tetap berkembang telah ikut berkontribusi bagi penerimaan negara. Pemerintah bisa mendapatkan pajak dari perusahaan-perusahaan yang berinvestasi di Bali. Secara tidak langsung negara mendapatkan manfaat dari kehadiran LPD yang hadir untuk mempertahankan adat dan budaya, serta secara tidak langsung LPD telah berkontribusi bagi pajak melalui kontribusinya mempertahankan adat dan budaya yang diambil dari laba LPD, sedangkan apabila LPD membayar pajak tidak ada jaminan pajak yang dibayarkan akan kembali kepada desa adat untuk membiayai kegiatan yang terkait dengan adat dan budaya Bali.

\section{Kesadaran Dari Pelaku Usaha LPD Tertentu Terkait Adanya Kewajiban Perpajakan Yang Perlu Dijalankan LPD}

Peran LPD begitu besar dalam membantu kehidupan di desa Pakraman. Hal itu pula yang menjadikan LPD sampai saat ini tidak bersedia dikenakan pajak. Akan tetapi dari eksplorasi yang dilakukan peneliti terhadap para informan terungkap bahwa beberapa informan memiliki usaha dan memiliki NPWP sedangkan yang lainnya tidak memiliki usaha dan tidak memiliki NPWP, hanya saja mereka mengetahui tentang PBB. Para informan yang memiliki NPWP dan memiliki kegiatan usaha lain sejak lama menjadikan informan sadar bahwasanya di LPD terdapat kewajiban perpajakan. Informan yang memiliki NPWP memahami apabila suatu badan usaha memiliki kewajiban untuk memotong penghasilan karyawannya.

Informan yang memiliki NPWP memiliki kesadaran eksplisit (noema) bahwa LPD sebagai lembaga keuangan adat yang berperan meningkatkan kemakmuran harus tetap berjalan sesuai aturan negara bukan malah merusak tatanan sistem negara yang telah ada. Bagi informan, apabila memang ada ketentuan memperbolehkan badan usaha tidak berbadan hukum seperti LPD memiliki NPWP, maka perlu untuk ditindaklanjuti. Apabila hal tersebut dilakukan, maka informan menekankan perlunya konsistensi dan tidak tebang pilih dalam pelaksaannya oleh DJP. Kesadaran ini terbentuk karena pengalaman informan yang memiliki kegiatan usaha yang membuatnya memiliki pemahaman atas pajak dan pengalaman terkait interaksi dengan DJP. Kesadaran ini membentuk kesadaran lebih mendalam (noesis) bahwa badan usaha juga memiliki kewajiban perpajakan.

Hal berbeda ditunjukkan oleh informan yang tidak memiliki usaha dan NPWP. Mereka memiliki pemahaman bahwasanya NPWP hanya dimiliki oleh seseorang yang memiliki usaha. Pemahaman mereka atas pajak hanya sebatas PBB. Ketika peneliti melakukan ekplorasi lebih mendalam tentang kewajiban perpajakan, para informan dengan tegas memberikan pernyataan yang hampir sama, yaitu LPD dalam aktivitasnya tidak semata-mata menjadi lembaga keuangan yang berorientasi pada laba, melainkan memiliki tujuan lebih dari itu. Selain para informan yang tidak memiliki NPWP, informan menyadari bahwa LPD memiliki peran untuk membiayai kegiatan 
yadnya. Lebih lanjut, para informan memiliki kesadaran bahwasanya di provinsi Bali, adat, budaya dan agama menyatu. Pada titik tertentu adat dan budaya itu bisa menjadi beban karena telah terjadi perubahan pola kehidupan masyarakat dari yang sebelumnya didominasi oleh kehidupan adat dan budaya yang terkait dengan kehidupan masyarakat agraris yang kemudian cenderung menuju masyarakat yang hidup dari sektor jasa. Untuk Mempertahankan hal tersebut, LPD berperan penting untuk mempertahankan adat dan budaya Bali. Desa Pakraman dapat membiayai semua aktivitas ini dari laba yang diperoleh LPD. Berdasarkan hal tersebut, muncullah kesadaran dari para informan dengan memaknai mengapa laba LPD tidak dikenai pajak, bukan karena 20\% laba kembali ke desa Pakraman, namun lebih dari itu, semua laba LPD digunakan untuk kepentingan desa Pakraman serta digunakan untuk mempertahankan adat dan budaya Bali.

Pemahaman seseorang terhadap pajak yang dipengaruhi karena interaksi dengan pajak melalui seperti misalnya kepemilikan NPWP, atau telah memiliki pengetahuan tentang pajak yang memadai dengan yang belum menjalankan kewajiban perpajakan serta tidak memahami tentang peraturan perpajakan yang berbeda bukan hal yang aneh. Sugiono, Ludigdo, dan Baridwan (2015) dalam penelitiannya terkait pemahaman pedagang kaki lima (PKL) terhadap pajak menemukan hal serupa dengan hasil penelitian ini. Para PKL tidak bisa membedakan mana yang termasuk retribusi dan mana yang merupakan pajak. Retribusi yang dibayar bagi mereka juga merupakan bentuk telah membayar pajak karena bagi mereka hal tersebut memiliki tujuan yang sama yaitu sebagai wujud tanggung jawab sosial, alat menuju ketenangan, wujud tanggung jawab sosial, mengasah budaya malu, serta sarana berbagi dengan sesama. Astari (2016) juga menemukan adanya hubungan yang positif antara kesadaran membayar pajak dengan kepemilikan NPWP, kemauan membayar pajak akan meningkat apabila seseoarang telah memiliki NPWP.

\section{Perlawanan Atas Distribusi Pendapatan Dari Sektor Pariwisata}

Perkembangan perekonomian Bali yang begitu pesat dirasakan oleh beberapa informan tidak memberikan manfaat maksimal bagi masyarakat Bali, pariwisata budaya hanya menjadi komoditi. Hasil yang diperoleh oleh investor dengan memanfaatkan Bali sebagai objek penghasil laba pada akhirnya lebih banyak dibawa keluar Bali daripada yang kembali digunakan untuk membangun Bali dan juga untuk tetap mempertahankan adat dan budaya.Ketidakadilan ekonomi ini bukan saja disadari oleh informan penelitian. Gubernur Bali, I Made Mangku Pastika juga menyadari hal tersebut. Bali menurutnya menjadi penghasil devisa yang cukup besar bagi negara, akan tetapi hanya mendapatkan kontribusi bagi hasil yang kecil karena pariwisata tidak dihitung dalam perhitungan dana bagi hasil. Devisa negara yang diperoleh dari Bali diklaim mencapai Rp47 triliun pada tahun 2015, tetapi hanya menerima dana bagi hasil dari pemerintah pusat sebesar Rp5 triliun. Pastika menyatakan bahwa dari APBD Provinsi Bali tahun 2015 sebesar Rp5 triliun, hampir Rp1 triliun dialokasikan untuk memelihara dan melestarikan adat dan budaya Bali (Liputan6.com, 2015).

Dana APBD sebesar Rp1 triliun tersebut dialokasikan kepada 1.488 desa pakraman. Setiap desa pakraman mendapatkan bantuan sebesar Rp200 juta. Jumlah yang terlihat besar, tetapi sebenarnya masih dirasa kecil untuk membiayai berbagai aktivitas di desa pakraman dalam rangka melestarikan adat dan budaya Bali. Peran inilah yang kemudian diambil oleh LPD untuk membantu desa pakraman melalui 20\% laba LPD yang diserahkan ke desa adat. Selain 20\% dari laba yang diberikan kepada desa adat, $5 \%$ dari laba LPD digunakan untuk dana sosial. Kegiatan yang diadakan melalui dana sosial ini seperti memberikan beasiswa bagi anak-anak dari krama desa, tirta yatra, dan lain-lain. Karena mengambil tanggung jawab untuk melestarikan adat dan budaya Bali, maka kemudian para informan merasa bahwa beban yang ditanggung LPD sudah berat, makin bertambah berat apabila ditambah dengan kewajiban untuk membayar pajak penghasilan. Pada titik inilah kemudian informan memiliki kesadaran bahwa apabila LPD membayar pajak, tidak ada kontribusi langsung yang bisa dirasakan oleh desa pakraman terkait pelestarian adat dan budaya Bali, padahal membayar pajak itu menurut informan bertujuan untuk pembangunan. 
Temuan penelitian ini sejalan dengan penelitian sebelumnya yang dilakukan oleh Darmayasa dan Aneswari (2016), kontribusi LPD melalui 20\% laba yang dikontribusikan ke desa dan 5\% laba digunakan untuk aktivitas sosial merupakan bentuk kepatuhan pajak. Penelitian mereka juga menemukan bahwa LPD bersedia membayar pajak apabila pemerintah bersedia untuk membiayai pembangunan dan perbaikan pura serta membiayai segala kebutuhan pura yang selama ini mengandalkan pendanaan dari krama. Penolakan membayar pajak karena alasan yang sama, tidak ada imbal balik langsung bagi masyarakat untuk membiayai aktivitas-aktivitas adat dan budaya yang melekat dengan aktivitas keagamaan sebagai satu kesatuan.

\section{Adanya Perlawanan Dari Masyarakat Adat Apabila Memaksakan Menjadi LPD Sebagai Subjek Dan Objek Pajak}

Pihak fiskus sebenarnya sudah lama meyakini LPD merupakan subjek pajak dan perlu memiliki NPWP karena memenuhi definisi sebagai badan berdasarkan ketentuan perpajakan. Penghasilan yang diperoleh LPD seharusnya merupakan objek pajak. Apabila dipaksakan untuk menetapkan NPWP secara jabatan terhadap LPD dapat menimbulkan perlawanan yang melibatkan hampir seluruh desa adat di Bali. Dari 1.488 desa adat di Bali hanya 55 desa adat yang tidak memiliki LPD. Risiko konflik dan perlawanan ini tidak bisa dilepaskan dari cara pandang yang berbeda dalam memaknai kewajiban pajak dan adanya rasa ketidakadilan. Sebagaimana yang peneliti temukan, informan yang merupakan pelaku usaha LPD secara tersirat memandang pajak adalah beban yang mengurangi kontribusi LPD bagi desa adat dalam mempertahankan adat dan budaya Bali, ditambah lagi dengan pemahaman bahwa UU LKM telah mengecualikan LPD dari kewajiban perpajakan.

Kesadaran para informan yang juga pelaku usaha LPD menitikberatkan pada kepentingan adat dan keagamaan ini tidak bisa dilepaskan dari pengaruh nilai dan tradisi yang dianut. Max Weber menyebutkan empat hal yang dapat memotivasi mekanisme perilaku seseorang yaitu, rasionalitas instrumental, rasionalitas nilai, pengaruh, dan tradisi (Hechter dan Horne, 2003). Pada titik ini terlihat bahwa nilai dan tradisi yang dimiliki informan yang dipengaruhi oleh adat dan budaya Bali yang bernafaskan Hindu memengaruhi tindakan mereka dalam memandang kewajiban pajak LPD. Pajak bukan yang utama, kepentingan adat dan budaya adalah yang utama. Kehadiran LPD yang dalam kegiatan usahanya menekankan pada filosofi THK, tercermin dari kontribusi laba untuk aktivitas parhyangan, palemahan, dan pawongan melebihi sekedar memenuhi kewajiban perpajakan melainkan kewajiban kepada Ida Sang Hyang Widhi Wasa. Oleh karena itu LPD pada posisi tersebut bagi mereka tidak pantas untuk dikenakan pajak penghasilan.

Perlawanan yang menurut peneliti bisa jadi jauh lebih besar daripada perlawanan menolak reklamasi Teluk Benoa yang saat ini sedang gencar di Bali. Pada aksi penolakan reklamasi Teluk Benoa, tidak banyak desa adat yang terlibat dalam aksi, hanya 38 desa adat dari 1000-an desa adat yang menjadi pendukung utama menolak reklamasi (Cnnindonesia.com, 2016). Desa adat yang lain cenderung pasif pada kasus ini. Akan berbeda lagi apabila menyangkut LPD. Sebagian besar desa adat di Bali memiliki LPD, karena itu perlawanan yang timbul tentu saja melibatkan desa adat dalam jumlah yang lebih besar karena ada dampak langsung yang akan dirasakan. Laba LPD yang diberikan ke desa pakraman untuk aktivitas di desa, serta untuk kegiatan sosial akan berkurang sebagai dampak dari pengenaan pajak.

Perlawanan terkait eksistensi LPD sudah berlangsung lama. Kesemuanya bermuara agar LPD tidak disamakan dengan lembaga keuangan serta tidak dikenakan pajak. Sebagaimana hasil penelitian Jolloh (2001) dan Kurniasari (2007) masyarakat Bali, yang diwakili oleh pemerintah provinsi tidak jarang berkonflik dengan pemerintah pusat terkait keberadaan LPD. Salah satunya adalah LPD tidak menjadi subjek dan objek pajak. Semua perlawanan tersebut bermuara pemahaman bahwasanya LPD bukan merupakan lembaga keuangan yang profit oriented. LPD memiliki tujuan memajukan masyarakat desa pakraman secara ekonomi, sehingga mencapai tingkat kesejahteraan yang layak. 


\section{SIMPULAN DAN SARAN Simpulan}

Penelitian ini bertujuan mengungkap kesadaran dari pelaku usaha LPD yang melatarbelakangi mengapa LPD tidak menjalankan kewajiban perpajakan sesuai dengan peraturan perpajakan yang berlaku di Indonesia. Hasil penelitian menunjukkan bahwa kesadaran pelaku usaha LPD terhadap pajak dan kesadarannya untuk tidak menjalankan kewajiban perpajakan sebagaimana mestinya atas kegiatan usaha LPD dikarenakan beberapa hal penting, yaitu: (1) LPD harusnya dibebaskan dari kewajiban perpajakan; karena pajak merupakan beban yang mengurangi kontribusi LPD; (2) LPD telah berperan besar melestarikan adat dan budaya Bali; (3) Kesadaran dari pelaku usaha LPD tertentu terkait adanya kewajiban perpajakan yang perlu dijalankan LPD; (4) LPD berperan penting dalam mempertahankan adat dan budaya Bali. Dalam hal ketidaksediaan LPD untuk membayar pajak dipengaruhi oleh rasa ketidakadilan atas distribusi pendapatan dari sektor pariwisata; serta (5) adanya perlawanan dari masyarakat adat apabila memaksakan menjadikan LPD sebagai subjek dan objek pajak.

Penelitian ini memberikan kontribusi baik secara teoritis maupun secara praktis. Secara teoritis, penelitian ini dapat menambah khasanah pengetahuan terkait suatu lembaga ekonomi yang bergerak dengan filosofi spiritual Hindu dikaitkan dengan pelaksanaan kewajiban perpajakan. Penelitian ini juga bisa memberikan perspektif baru terkait subjek (pelaku usaha LPD) yang memiliki kesadaran berbeda dalam memandang kewajiban perpajakan. Kontibusi praktis dari penelitian ini adalah sebagai bahan masukan dalam mengatasi perbedaan pendapat terkait status perpajakan LPD dari sudut pandang LPD dan dari sudut pandang fiskus.

\section{Saran}

Kendala yang dihadapi dalam penelitian ini ialah keterbatasan jangka waktu penyelesaian penelitian dan susahnya memperoleh waktu untuk bertemu dengan informan. Kesibukan informan ini peneliti rasakan ketika ingin mewawancarai salah satu informan membutuhkan waktu satu bulan sampai akhirnya dapat bertemu. Selain itu, peneliti juga tidak dapat melakukan pertanyaan yang mendalam karena terkendala posisi peneliti yang merupakan pegawai DJP. Hal lain yang menjadikan peneliti tidak dapat menggali lebih dalam karena pada tahap awal peneliti telah merasakan adanya resistensi atas pembahasan LPD dan pajak. Untuk menghindari resistensi frontal dari informan, maka peneliti tidak dapat melakukan proses bracketing yang maksimal untuk menggali lebih dalam makna pajak atas kewajiban perpajakan LPD.

Peneliti selanjutnya mungkin dapat meneliti lebih jauh terkait pendapat bahwa apa yang diterima Bali dari pemerintah pusat tidak sebanding dengan penerimaan yang diterima negara dari pariwisata Bali dan kemudian dibandingkan dengan dana perimbangan yang diterima oleh provinsi dan kabupaten/kota di Bali. Serta perlu dilakukan penelitian sejenis dengan mengambil kasus pada keberadaan Lumbung Pitih Nagari (LPN) di Sumatera Barat.

\section{DAFTAR RUJUKAN}

Ajzen, I. 1991. The Theory of Planned Behavior. Organizational Behavior and Human Decision Processes, 50: 179-211.

Astari, E. A. Pengaruh Tingkat Pendidikan Dan Pemahaman Wajib Pajak Terhadap Kemauan Membayar Pajak Melalui Kesadaran Wajib Pajak Orang Pribadi Memiliki Npwp Sebagai Variabel Intervening (Studi Kasus Pada Masyarakat Di Kota Samarinda, Kalimantan Timur). Skripsi, Program Studi Akuntansi, Fakultas Ekonomi, Universitas Muhammadiyah Yogyakarta.

Astawa, I. P. 2012. Kepemilikan Institusi dan Nilai-Nilai Harmoni dalam Meningkatkan Kinerja Keuangan Lembaga Perkreditan Desa di Provinsi Bali. Disertasi, Program Doktor Ilmu Manajemen, Pascasarjana Fakultas Ekonomi dan Bisnis Universitas Brawijaya. 
Bagiada, I. M., dan Darmayasa, I. N. 2015. Implementasi Filosofi Tri Hita Karana Dalam Pengungkapan Tanggung Jawab Sosial Pada Lembaga Perkreditan Desa (LPD). Simposium Nasional Akuntansi Vokasi IV. 798-815.

Bank Indonesia Perwakilan Bali. 2015. Kajian Ekonomi dan Keuangan Regional Provinsi Bali Triwulan III 2015. Bank Indonesia. Denpasar.

Baskara. 2013. Lembaga keuangan mikro di Indonesia. Jurnal Buletin Studi Ekonomi, 18(2): 114125.

Bisnis.Com. 2015. Aset LPD Di Bali Rp14,2 Triliun. http://bali.bisnis.com/read/20151214/3/56039/aset-lpd-di-bali-rp142-triliun, diakses 5 February 52016.

Bohari, H. 2001. Pengantar Hukum Pajak. PT. Rajagrafindo Persada. Jakarta.

Budiasih, I. G. A. N. 2014. Fenomena Akuntabilitas Perpajakan Pada Jaman Bali Kuno: Suatu Studi Interpretif. Jurnal Akuntansi Multiparadigma, 5(3): 409-420.

Burell, G., dan Morgan, G. 1979. Sociological Paradigms And Organisational Analysis. Ashagate Publishing Limited. Aldershot, England.

Cnnindonesia.com. 2016. Desa Adat Seminyak Gelar Aksi Tolak Reklamasi Teluk Benoa. http://www.cnnindonesia.com/nasional/20161119225801-20-173845/ desa-adatseminyak-gelar-aksi-tolak-reklamasi-teluk-benoa/, diakses 5 Januari 2016

Damayanthi, I. G. A. E. K. A. 2011. Pengungkapan Tanggung Jawab Sosial Lembaga Perkreditan Desa (LPD) Berdasarkan filosofi Tri Hita Karana. Jurnal Ilmiah Akuntansi dan Bisnis. 117.

Darmayasa, I. N., dan Aneswari, R. Y. 2016. The Role of Local Wisdom Toward Tax Compliance. Jurnal Akuntansi Multiparadigma, 7(1):110-119.

Djayastra, I. K. 2012. Peranan Lembaga Perkreditan Desa Dalam pemberdayaan Ekonomi Masyarakat Desa Adat Berlandaskan Modal Sosial (Studi Kasus: Desa Adat KedongananKuta Kabupaten Badung Provinsi Bali. Disertasi Program Doktor Ilmu Ekonomi Pascasarjana Fakultas Ekonomi and Bisnis Universitas Brawijaya

Jolloh, D. 2001. Promotion of Small Financial Institutions ProFI Microfinance Institutions Study. Denpasar.

Fidiana. 2014. Eman dan Iman : Dualisme Kesadaran dan Kepatuhan. Seminar Nasional Akuntansi 17. Mataram.

Gunawan, K. 2011. Peran Falsafah Tri Hita Karana Bagi Pertumbuhan dan Kinerja Lembaga Perkreditan Desa (LPD) Di Bali. Jurnal Analisis Manajemen, 5(2); 23-36.

Hechter, M., \& Horne, C. 2003. Theories Of Social Order: A Reader. California: Stanford University Press.

Kamayanti, A. 2016. Metodelogi Penelitian Kualitatif Akuntansi: Pengantar religiositas Keilmuan. Yayasan Rumah Peneleh. Surabaya.

Kariyoto, Subroto, B., Sutrisno, dan Rosidi. 2010. Pengaruh Kesadaran dan Kepatuhan Wajib Pajak Terhadap Kinerja Perpajakan (Studi Pada Kanwil Ditjen Pajak Jawa Timur III). Jurnal Akuntansi Multiparadigma, 3(1): 62-76.

Kementerian Keuangan. 2016b. Siaran Pers Penerimaan Negara Tahun 2015. from http://kemenkeu.go.id/sites/default/files/SP-012016.pdf. Diakses 3 February 2016

Kurniasari, T. W. 2007. Lembaga Perkreditan Desa Dalam Perspektif Hukum; Sebuah Lembaga Keuangan Adat Hindu Penggerak Usaha Sektor Informal Di Bali. Jurnal Masyarakat dan Budaya, 9(1): 53-78.

Kuswarno, E. 2009. Metodologi Penelitian Komunikasi Fenomenologi: Konsepsi, Pedoman dan Contoh Penelitian. Widya Pajajaran. Bandung.

Liputan6.com. 2015. Gubernur Sebut Dana Bagi Hasil untuk Bali Tidak Adil. (2015).http://regional.liputan6.com/read/2334588/gubernur-sebut-dana-bagi-hasil-untukbali-tidak-adil. diakses 12 November 2016. 
Moleong, L. J. 2014. Metodologi Penelitian Kualitatif Edisi Revisi (Edisi 33). PT Remaja Rosdakarya. Bandung.

Nurjaya, I. N. 2011. Lembaga Perkreditan Desa di Bali dalam Perspektif Antropologi Hukum. Landasan Teoretik Pengaturan LPD Sebagai Lembaga Jeuangan Komunitas Masyarakat Hukum Adat di Bali. Udayana University Press. Denpasar.

Pemerintah Republik Indonesia. 2013. Undang-Undang Nomor 1 Tahun 2013 Tentang Lembaga Keuangan Mikro.

Pertiwi, I. D. A. E. dan Ludigdo, U. 2013. Implementasi Corporate Social Responsibility Berlandaskan Budaya Tri Hita Karana. Jurnal Akuntansi Multiparadigma, 4(3): 430-455.

Smith, A. 1952. An Inquiry into the Nature and Causes of the Wealth of Nations. Encyclopædia Britannica. London: Chicago.

Sugiono, A., Ludigdo, U., dan baridwan, A. 2015. Makna Pajak dan Retribusi: Perspektif Wajib Pajak Pedagang Kaki Lima. Jurnal Akuntansi Multiparadigma, 6(1): 53-78.

Sukandia, I. N. 2011. Sifat Suigeneris LPD Sebagai Lembaga Keuangan Komunitas Dalam Pengaturan LPD Sebagai Lembaga Keuangan Komunitas Pada Masyarakat Desa Pakraman. Landasan Teoretik Pengaturan LPD Sebagai Lembaga Jeuangan Komunitas Masyarakat Hukum Adat di Bali. Udayana University Press. Denpasar.

Sukoharsono, E. G., dan Qudsi, N. 2008. Accounting in the Golden Age of Singosari Kingdom : A Foucauldian Perspective. Simposium Nasional Akuntansi XI, Pontianak, 1-21.

Sumarsan, T. 2015. Perpajakan Indonesia: Pedoman Perpajakan Lengkap Berdasarkan UndangUndang Terbaru Edisi 4. PT Indeks. Jakarta.

Sutanto, P. M. 2014. Perpajakan Indonesia. Mitra Wacana Media. Jakarta.

Torgler, B. 2004. Tax morale in Asian countries. Journal of Asian Economics, 15(2): 237-266.

Torgler, B. 2006. The importance of faith: Tax morale and religiosity. Journal of Economic Behavior and Organization, 61(1): 81-109.

Waluyo. 2001. Perpajakan Indonesia. Salemba Empat. Jakarta. 